\title{
Hubungan Faktor-faktor yang Berperan untuk Terjadinya Dismenore pada Remaja Putri di Era Normal Baru
}

\author{
Nancy H. Kojo, Theresia M. D. Kaunang, Angelheart J. M. Rattu
}

Program Studi Magister Ilmu Kesehatan Masyarakat Universitas Sam Ratulangi, Manado, Indonesia

E-mail: kojonancyy@gmail.com

\begin{abstract}
Since Covid-19 is still a pandemic worldwide, people are required to familiarize themselves with new normal lifes or new normal conditions that have been implemented in Indonesia. Observation at Tincep Village of Minahasa during April to October 2020 revealed that the village government was very strict in implementing social restrictions; therefore, teenagers or young people were rarely doing physical activity outdoors. Moreover, teenagers with low physical activity tended to prefer indoor activities. This study was aimed to analyze the relationship between influencing factors of dysmenorrhea in female teenagers in the new normal era. This was a quantitative analytical and descriptive study with a cross sectional design. This study was conducted from November to December 2020 at Tincep Village. Subjects were 40 female teenagers aged 12-18 years. Independent variables were physical activity, nutritional status, age of menarche, length of menstruation, and depression meanwhile dependent variables was dysmenorrhea. Data were statistical analyzed univariately and bivariately. The results showed that significant relationships were only obtained between physical activity and depression and dysmenorrhea among female teenagers at Tincep Village, Minahasa in the new normal era. In conclusion, factors associated with dysmenorrhea were physical activity (most dominant) and depression meanwhile factors that were not associated with dysmenorrhea included nutritional status, age of menarche, and duration of menstruation.
\end{abstract}

Keywords: new normal; dysmenorrhea; Covid-19

\begin{abstract}
Abstrak: Covid-19 masih menjadi wabah yang belum dapat diatasi di seluruh dunia. Oleh karena itu masyarakat dituntut untuk membiasakan diri dengan hidup new normal atau keadaan normal baru yang sudah diterapkan di Indonesia. Dari hasil pengamatan di desa Tincep Kabupaten Minahasa selama bulan April sampai Oktober 2020, ternyata pemerintah desa sangat ketat menjalankan kebijakan yaitu pembatasan sosial sehingga jarang remaja atau pemuda melakukan aktivitas fisik di luar rumah. Penelitian ini bertujuan untuk menganalisis hubungan faktor-faktor yang berperan untuk terjadinya dismenore pada remaja desa di era normal baru. Jenis penelitian ialah kuantitatif deskriptif analitik dengan desain potong lintang. Penelitian ini dilaksanakan di Desa Tincep Kabupaten Minahasa pada November - Desember 2020. Subyek penelitian ini yaitu 40 remaja putri yang berusia 12-18 tahun. Variabel bebas penelitian ini yaitu aktivitas fisik, status gizi, usia menarche, lama menstruasi, dan depresi dan variabel terikat ialah dismenore. Data hasil penelitian dianalisis secara univariat, bivariat, dan multivariat. Penyajian data dibuat dalam bentuk tabel dan narasi. Hasil penelitian ini menunjukkan bahwa hubungan bermakna hanya didapatkan antara aktivitas fisik dan depresi dengan dismenore pada remaja putri di Desa Tincep Kabupaten Minahasa di era normal baru. Simpulan penelitian ini ialah faktor-faktor yang berhubungan dengan dismenore ialah aktivitas fisik (yang terutama) dan depresi. Faktor-faktor yang tidak berhubungan dengan dismenore meliputi status gizi, usia menarche, serta lama menstruasi.
\end{abstract}

Kata kunci: new normal; dismenore; Covid-19 


\section{PENDAHULUAN}

Masa remaja merupakan masa perkembangan diri yang sangat penting, diawali dengan matangnya organ-organ fisik (organ kelamin) sehingga nantinya mampu bereproduksi. Pada masa remaja terdapat banyak perubahan yang terjadi seperti perubahan hormonal, fisik, psikologis, maupun sosial; kondisi tersebut dinamakan masa pubertas. Salah satu tanda pubertas pada remaja putri yaitu terjadinya menstruasi. ${ }^{1}$

Menstruasi terjadi saat lapisan dalam dinding rahim luruh dan keluar dalam bentuk yang dikenal dengan istilah darah menstruasi. Dalam keadaan normal, setiap bulan seorang wanita yang telah memasuki usia subur melepaskan satu sel telur (ovum), dan ovum yang dihasilkan akan dilepaskan oleh indung telur (ovarium). ${ }^{2}$ Menstruasi yang pertama kali didapatkan oleh seorang wanita disebut dengan istilah menarche. Pada saat menstruasi, masalah yang dialami oleh hampir sebagian besar wanita ialah rasa tidak nyaman sampai dengan rasa nyeri yang hebat; hal ini disebut sebagai nyeri haid (dismenore). Menurut data World Health Organitation (WHO), angka kejadian dismenore di Indonesia sebanyak 55\% di kalangan usia produktif, dengan $15 \%$ di antaranya mengeluhkan aktivitas menjadi terbatas akibat dismenore. ${ }^{3}$

Dismenore didefinisikan sebagai sensasi sakit, kram di perut bagian bawah yang sering disertai dengan gejala lain seperti berkeringat, sakit kepala, mual, muntah, diare, dan gemetaran, kesemuanya terjadi tepat sebelum atau selama menstruasi. Terdapat dua jenis dismenore yaitu dismenore primer dan sekunder. Dismenore primer mengacu pada rasa sakit tanpa penyakit panggul patologik yang jelas dan hampir selalu terjadi pertama kali pada wanita 20 tahun atau lebih muda setelah siklus ovulasi mereka menjadi tetap. Dismenore sekunder disebabkan oleh kondisi panggul patologik yang mendasarinya dan lebih sering terjadi pada wanita yang berusia lebih dari 20 tahun. $^{4}$

Prevalensi dismenorea yang dilaporkan dalam literatur bervariasi. Prevalensi yang lebih besar umumnya diamati pada wanita muda, dengan perkiraan mulai dari $67 \%$ hingga $90 \%$ untuk mereka yang berusia $17-$ 24 tahun. Penelitian di Australia terhadap anak perempuan Sekolah Menengah Atas mendapatkan bahwa 93\% dari remaja melaporkan mengalami rasa sakit disaat menstruasi. ${ }^{5}$ Penelitian tentang pola dismenore primer pada remaja di Madrasah Aliyah Negeri 1 Semarang menyatakan bahwa sebagian besar responden mengalami dismenore $(65,2 \%)$ setiap kali menstruasi. Gejala dismenore yang dirasakan sebagian besar responden ialah nyeri pada perut bagian bawah menjalar sampai punggung dan tungkai $(91,3 \%)$, rasa pegal pada kaki $(73,9 \%)$, dan rasa pegal pada pinggang $(76,1 \%)$. Interval dismenore yang terjadi lebih dari tiga tahun setelah menarche (47,8\%), lebih banyak daripada 2-3 tahun $(47,8 \%)$ dan kurang dari 2 tahun $(13 \%){ }^{6}$

Hong et $\mathrm{al}^{7}$ meneliti prevalensi dan faktor risiko dismenore dengan menelusuri 15 penelitian utama terbitan antara 2002 dan 2011. Hasil penelitiannya mendapatkan bahwa prevalensi dismenore bervariasi antara $16 \%$ dan $91 \%$ pada wanita usia reproduktif, dengan rasa sakit tergolong parah pada $2-29 \%$ dari wanita yang diteliti. Stres yang tinggi meningkatkan risiko dismenore. Adanya riwayat keluarga dismenore sangat meningkatkan risikonya, dengan rasio odds antara 3,8 dan 20,7. Hong et al menyimpulkan bahwa dismenore merupakan gejala yang bermakna untuk wanita usia reproduktif namun rasa sakit parah yang membatasi kegiatan sehari-hari kurang umum. Selain itu, Hong et al menegaskan bahwa dismenore meningkat dengan bertambahnya usia, paritas, serta terkait dengan stres dan riwayat keluarga dismenore.

Habibi et $\mathrm{al}^{8}$ melakukan penelitian dengan desain potong lintang terhadap 311 mahasiswa wanita berusia 18 hingga 27 tahun di Isfahan University of Medical Sciences, Iran. Karakteristik sosiodemografi dan faktor menstruasi diperoleh melalui wawancara dengan bantuan kuesioner. Prevalensi dismenore primer diperoleh sebesar $89,1 \%$. Faktor yang secara bermakna terkait dengan intensitas dismenore primer ialah usia yang lebih muda, pendi- 
dikan formal yang rendah, riwayat keluarga dismenore, perdarahan lebih banyak, dan periode interval menstruasi yang lebih pendek.

Coronavirus adalah zoonosis atau virus yang ditularkan antara hewan dan manusia. Virus dan penyakit ini diketahui berawal di kota Wuhan, Cina sejak Desember 2019. Corona virus 2019 (Covid-19) telah dinyatakan sebagai pandemi dunia oleh WHO. ${ }^{9}$ Per tanggal 24 April 2021, yang terdeteksi positif sebanyak 1,63 juta orang, yang meninggal sebanyak 44.172 orang dan yang sembuh sebanyak 1,48 juta orang. Di Sulawesi Utara, data per tanggal 24 April 2021, positif sebanyak 15,560 orang, meninggal sebanyak 521 orang dan sembuh sebanyak 13,075 orang. ${ }^{10}$

Skenario new normal Indonesia mulai disosialisasikan oleh pemerintah melalui Kementerian Kesehatan RI pada bulan Mei 2020. Covid-19 masih menjadi wabah yang belum bisa diatasi bukan saja di Indonesia tetapi diseluruh dunia. Berbagai negara di dunia telah mengakui kalau dunia tidak akan kembali seperti semula dan banyak yang memulai untuk berusaha beradaptasi dengan ovid-19. Oleh karena itu masyarakat dituntut untuk membiasakan diri dengan hidup new normal atau keadaan normal baru yang telah diterapkan di Indonesia. Protokol kesehatan yang diterapkan di era new normal ini ialah rajin mencuci tangan, menghindari keramaian, menjaga jarak, dan memakai masker ketika keluar rumah. ${ }^{10}$

Pada pengamatan di desa Tincep Kabupaten Minahasa selama bulan April sampai Oktober 2020 ternyata pemerintah desa sangat ketat menjalankan kebijakan yaitu pembatasan sosial sehingga jarang kelihatan remaja atau pemuda/i melakukan aktivitas fisik di luar rumah misalnya bermain voli, berjalan, dan berkebun. Secara teoritis, dengan melakukan aktivitas fisik yang teratur atau melakukan olahraga, tubuh akan menghasilkan endorfin. Hormon ini dapat berfungsi sebagai agen penenang alami yang diproduksi oleh otak sehingga menimbulkan rasa nyaman termasuk mengurangi dismenore. Remaja dengan aktivitas fisik rendah cenderung menyukai kegiatan di dalam ruangan misalnya menonton TV berjam-jam, main komputer, tidur dalam waktu lama, dan menghabiskan waktu untuk bermain gadget. Hal ini yang mendorong penulis untuk mengetahui lebih lanjut dan menganalisis hubungan faktorfaktor yang berperan dalam terjadinya dismenore pada remaja di desa di samping faktor internal dan eksternal lainnya. ${ }^{11}$

\section{METODE PENELITIAN}

Penelitian ini dilakukan di Desa Tincep Kabupaten Minahasa Tenggara pada bulan November-Desember 2020. Jenis penelitian ini ialah kuantitatif deskriptif analitik dengan desain potong lintang. Populasi penelitian ini yaitu seluruh remaja putri berusia 12-18 tahun di Desa Tincep Kabupaten Minahasa yang berjumlah 40 orang dengan teknik pengambilan sampel secara total sampling. Alasan mengambil total sampling yaitu pada populasi yang kurang dari 100 maka seluruh populasi dijadikan sampel penelitian. ${ }^{12}$ Turun lapangan dilakukan selama dua minggu. Variabel bebas penelitian ini yaitu aktivitas fisik, status gizi (dinilai dari indeks massa tubuh/IMT), usia menarche, lama menstruasi, dan depresi sedangkan variabel terikat ialah dismenore. Instrumen penelitian menggunakan kuesioner dan Depression Hamilton Scale. Pertanyaan yang ditanyakan yaitu tentang identitas dan karakteristik subjek. Data hasil penelitian dianalisis secara univariat, bivariat, dan multivariat. Penyajian data dibuat dalam bentuk tabel dan narasi.

\section{HASIL PENELITIAN}

Responden dalam penelitian ini ialah remaja putri di Desa Tincep Kabupaten Minahasa. Tabel 1 memperlihatkan bahwa responden terbanyak berusia 16-18 tahun sebanyak $23(57,5 \%)$ remaja dan 13-15 tahun sebanyak 17 (42,5\%) remaja. Responden dengan status gizi normal sebanyak 33 remaja $(82,5 \%)$, responden dengan status gizi kurang 3 remaja $(7,5 \%)$, dan responden dengan status gizi lebih 4 remaja $(10,0 \%)$. 
Tabel 1. Karakteristik responden di Desa Tincep Kabupaten Minahasa

\begin{tabular}{lcc}
\hline $\begin{array}{c}\text { Karakteristik } \\
\text { responden }\end{array}$ & $\begin{array}{c}\text { Frekuensi } \\
(\mathbf{n})\end{array}$ & $\begin{array}{c}\text { Persentase } \\
(\mathbf{\%})\end{array}$ \\
\hline Usia (tahun) & & \\
$\quad 13-15$ & 17 & 42,5 \\
$16-18$ & 23 & 57,5 \\
Status gizi & & \\
Underweight & 3 & 7,5 \\
Normal & 33 & 82,5 \\
Overweight & 4 & 10,0 \\
Total & 40 & 100,0 \\
\hline
\end{tabular}

Berdasarkan aktivitas fisik diperoleh sebanyak 29 responden $(72,5 \%)$ dengan aktivitas fisik $\geq 30$ menit dan sebanyak 11 responden $(27,5 \%)$ dengan aktivitas fisik $<30$ menit. Berdasarkan usia menarche didapatkan sebagian besar responden yaitu sebanyak 29 orang $(72,5 \%)$ dengan usia menarche $\geq 11$ tahun dan responden dengan usia menarche $<11$ tahun sebanyak 11 orang $(27,5 \%)$. Berdasarkan lama menstruasi didapatkan sebagian besar responden dengan lama menstruasi $<7$ hari, yaitu sebanyak 35 orang $(87,5 \%)$ dan responden dengan lama menstruasi $\geq 7$ hari sebanyak 5 orang $(12,5 \%)$. Berdasarkan adanya dismenore diketahui sebagian besar responden tidak mengalami dismenore yaitu sebanyak 32 orang $(80,0 \%)$, dan responden yang mengalami dismenore sebanyak 8 orang $(20,0 \%)$.

Tabel 2 memperlihatkan bahwa sebagian besar responden tidak mengalami depresi, yaitu 26 orang $(65,0 \%)$ diikuti depresi ringan sebanyak 11 orang $(27,5 \%)$, depresi sedang sebanyak $3(7,5 \%)$. Tidak didapatkan responden dengan depresi berat dan depresi sangat berat $(0 \%)$.

Tabel 3 memperlihatkan bahwa responden yang melakukan aktivitas fisik <30 menit dan mengalami dismenore sebanyak 7 orang $(17,5 \%)$, sedangkan yang melakukan aktivitas fisik $\geq 30$ menit dan mengalami dismenore hanya satu orang $(2,5 \%)$. Hasil perhitungan Chi-Square memperoleh nilai $\mathrm{p}=0,000<\alpha=0,05$.

Tabel 4 memperlihatkan bahwa bahwa sebagian besar responden dengan status gizi normal dan tidak mengalami dismenore yaitu sebanyak 26 orang $(65,0 \%)$. Hasil perhitungan Chi-Square memperoleh nilai $\mathrm{p}=0,506>\alpha=0,05$.

Tabel 5 memperlihatkan bahwa responden terbanyak dengan usia menarche $\geq 11$ tahun dan tidak mengalami dismenore sebanyak 23 orang $(57,5 \%)$ orang. Hasil perhitungan Chi-Square memperoleh nilai $\mathrm{p}=0,619>\alpha=0,05$.

Tabel 6 memperlihatkan bahwa sebagian besar responden dengan lama menstruasi $<7$ hari dan tidak mengalami dismenore yaitu sebanyak 28 orang $(70,0 \%)$ orang. Hasil perhitungan Chi-Square memperoleh nilai $\mathrm{p}=0,694>\alpha=0,05$.

Tabel 7 memperlihatkan bahwa responden dengan depresi ringan dan mengalami dismenore yaitu 4 orang (10\%) dan yang dengan depresi sedang dan mengalami dismenore yaitu tiga orang $(7,5 \%)$. Hasil perhitungan Chi-Square memperoleh nilai $\mathrm{p}=0,000<\alpha=0,05$.

Tabel 2. Depresi pada responden penelitian

\begin{tabular}{lcc}
\hline Depresi & $\begin{array}{c}\text { Frekuensi } \\
(\mathbf{n})\end{array}$ & $\begin{array}{c}\text { Persentase } \\
(\%)\end{array}$ \\
\hline Tanpa depresi & 26 & 65 \\
(normal) & 11 & 27,5 \\
Ringan & 3 & 7,5 \\
Sedang & 0 & 0 \\
Berat & 0 & 0 \\
Sangat berat & 40 & 100,0 \\
Jumlah & & \\
\hline
\end{tabular}


Tabel 3. Hubungan antara aktivitas fisik dengan dismenore pada responden penelitian

\begin{tabular}{lcccl}
\hline Aktivitas fisik & $\begin{array}{c}\text { Dismenore } \\
\text { Tidak } \\
\mathrm{n}(\%)\end{array}$ & $\begin{array}{c}\text { Total } \\
\mathrm{n}(\%)\end{array}$ & $\begin{array}{l}\chi^{2} \\
(p \text {-value })\end{array}$ \\
\hline$<30$ menit & 7 & 4 & 11 & \\
$\geq 30$ menit & 1 & 28 & 39 & 0,000 \\
Total & 8 & 32 & 40 & \\
\hline
\end{tabular}

Tabel 4. Hubungan antara status gizi dengan dismenore pada responden penelitian

\begin{tabular}{lllll}
\hline Status Gizi & \multicolumn{4}{c}{ Dismenore } \\
& Ya & Tidak & Total & $\chi^{2}$ \\
& $\mathrm{n}(\%)$ & $\mathrm{n}(\%)$ & $\mathrm{n}(\%)$ & $(p-$ value $)$ \\
\hline Underweight & 1 & 2 & 3 & \\
Normal & 7 & 26 & 33 & 0,506 \\
Overweight & 0 & 4 & 4 & \\
Total & 8 & 32 & 40 & \\
\hline
\end{tabular}

Tabel 5. Hubungan antara usia menarche dengan dismenore pada responden penelitian

\begin{tabular}{|c|c|c|c|c|}
\hline \multirow[t]{2}{*}{ Usia Menarche } & \multicolumn{3}{|c|}{ Dismenore } & \multirow[b]{2}{*}{$\begin{array}{l}\chi^{2} \\
(p \text {-value })\end{array}$} \\
\hline & $\begin{array}{l}\mathrm{Ya} \\
\mathrm{n}(\%)\end{array}$ & $\begin{array}{l}\text { Tidak } \\
\mathrm{n}(\%)\end{array}$ & $\begin{array}{l}\text { Total } \\
\mathrm{n}(\%)\end{array}$ & \\
\hline$<11$ tahun & 2 & 9 & 11 & \\
\hline$\geq 11$ tahun & 6 & 23 & 29 & 0,619 \\
\hline Total & 8 & 32 & 40 & \\
\hline
\end{tabular}

Tabel 6. Hubungan antara lama menstruasi dengan dismenore pada responden penelitian

\begin{tabular}{|c|c|c|c|c|}
\hline \multirow[t]{2}{*}{ Lama menstruasi } & \multicolumn{3}{|c|}{ Dismenore } & \multirow[b]{2}{*}{$\begin{array}{c}\chi^{2} \\
(p-\text { value })\end{array}$} \\
\hline & $\begin{array}{c}\mathrm{Ya} \\
\mathrm{n}(\%)\end{array}$ & $\begin{array}{l}\text { Tidak } \\
\mathrm{n}(\%)\end{array}$ & $\begin{array}{l}\text { Total } \\
\text { n }(\%)\end{array}$ & \\
\hline$<7$ hari & 7 & 28 & 35 & \\
\hline$\geq 7$ hari & 1 & 4 & 5 & 0,694 \\
\hline Total & 8 & 32 & 40 & \\
\hline
\end{tabular}

Tabel 7. Hubungan antara depresi dengan dismenore pada responden penelitian

\begin{tabular}{lcccc}
\hline \multicolumn{1}{c}{ Depresi } & $\begin{array}{c}\text { Ya } \\
\mathrm{n}(\%)\end{array}$ & $\begin{array}{c}\text { Dismenore } \\
\text { Tidak } \\
\mathrm{n}(\%)\end{array}$ & $\begin{array}{c}\text { Total } \\
\mathrm{n}(\%)\end{array}$ & $\begin{array}{c}\chi^{2} \\
(\boldsymbol{p} \text {-value })\end{array}$ \\
\hline Tanpa depresi (normal) & 1 & 25 & 26 & \\
Ringan & 4 & 7 & 11 & \\
Sedang & 3 & 0 & 3 & 0 \\
Berat & 0 & 0 & 0 & \\
Sangat berat & 0 & 0 & 0 & \\
Total & 8 & 32 & 40 & \\
\hline
\end{tabular}


Tabel 8 memperlihatkan hasil uji regresi logistik. Responden dengan aktivitas fisik memiliki kecenderungan terjadinya dismenore sebanyak 31,996 kali dibandingkan dengan depresi.

Tabel 8. Hasil uji regresi logistik

\begin{tabular}{lcc}
\hline \multicolumn{1}{c}{ Variabel } & $\begin{array}{c}\text { Nilai } \\
\text { Signifikansi }\end{array}$ & $\operatorname{Exp~(B)~}$ \\
\hline Aktivitas fisik & 0,015 & 31,996 \\
Depresi & 0,037 & 0,057 \\
\hline
\end{tabular}

\section{BAHASAN}

Hasil penelitian ini menunjukkan adanya hubungan bermakna antara aktivitas fisik dan dismenore. Hal ini sejalan dengan penelitian Handayani dan Rahayu ${ }^{13}$ yang melaporkan adanya hubungan bermakna antara aktivitas fisik dengan dismenore. Sumosardjuno $^{14}$ menyatakan dismenore lebih kurang terjadi pada olahragawati dibandingkan dengan wanita yang tidak pernah berolahraga. Salah satu cara yang sangat efektif untuk mencegah dismenore ialah dengan melakukan aktivitas fisik. Aktivitas fisik secara teratur seperti berjalan kaki, jogging, berlari, bersepeda, renang, atau senam aerobik dapat memperbaiki kesehatan secara umum dan membantu menjaga siklus menstruasi agar teratur. Seorang remaja wanita yang melakukan aktivitas fisik secara rutin dan teratur sebanyak dua atau lebih setiap minggu memiliki kecenderungan yang lebih kecil untuk menderita dismenore dibandingkan dengan remaja wanita yang melakukan aktivitas fisik tidak teratur atau kurang dari dua kali dalam satu minggu. ${ }^{15}$

Hasil penelitian ini menunjukkan bahwa tidak terdapat hubungan bermakna antara status gizi dengan dismenore. Berdasarkan studi sebelumnya individu dengan IMT kurang dan IMT lebih cenderung berisiko mengalami dismenore daripada yang dengan IMT normal. ${ }^{16,17}$ Semakin banyak deposit jaringan lemak maka semakin banyak pula prostaglandin yang dibentuk, sedangkan peningkatan kadar prostaglandin dalam sirkulasi darah diduga sebagai penyebab dismenorea. ${ }^{16}$ Kelebihan berat badan dapat mengakibatkan dismenore, karena di dalam tubuh individu dengan kelebihan berat badan terdapat jaringan lemak berlebihan yang dapat meningkatkan hiperplasi pembuluh darah (terdesaknya pembuluh darah oleh jaringan lemak) pada organ reproduksi wanita sehingga darah yang seharusnya mengalir pada saat proses menstruasi terganggu dan timbul dismenore. ${ }^{18}$ Faktor yang dapat menjadi penyebab ketidakbermaknaan antara lain sebanyak 26 responden remaja putri di Desa Tincep Kabupaten Minahasa ini memiliki IMT normal dan tidak mengalami dismenore.

Hasil penelitian ini menunjukkan tidak terdapatnya hubungan bermakna antara usia menarche dengan dismenore. Ketidakbermaknaan hubungan ini dapat disebabkan oleh faktor yang paling memengaruhi dalam dismenore, yaitu faktor hormonal yang berbeda-beda pada masing-masing individu sehingga efek yang ditimbulkan juga berbeda. Hasil penelitian ini selaras dengan penelitian yang dilakukan oleh Suwarnisih ${ }^{19}$ yang menyatakan bahwa tidak terdapat hubungan usia menarche dengan kejadian dismenore. Demikian pula pada penelitian yang dilakukan oleh Silvana ${ }^{17}$ ditemukan tidak adanya hubungan usia menarche dengan kejadian dismenore. Bila menarche terjadi pada usia yang lebih awal dari normal dimana alat reproduksi belum siap untuk mengalami perubahan dan masih terjadi penyempitan pada leher rahim maka akan timbul rasa sakit saat menstruasi. ${ }^{20}$

Hasil penelitian ini menunjukkan bahwa tidak terdapat hubungan bermakna antara lama menstruasi dengan dismenore. Hasil penelitian ini sejalan dengan penelitian yang dilakukan oleh Gustina ${ }^{21}$ yang menyatakan tidak terdapat hubungan antara lama menstruasi dengan dismenore. Penelitian ini juga sejalan dengan penelitian yang dilakukan oleh Silvana ${ }^{17}$ yang menyatakan tidak terdapat hubungan antara lama menstruasi dengan dismenore. Faktor yang menjadi penyebab ketidakbermaknaan antara lama menstruasi dengan dismenore ini antara lain sebanyak 28 responden memiliki lama menstruasi $<7$ hari dan tidak mengalami dismenore. Nyeri yang terjadi pada 
dimenore muncul sesaat sebelum menstruasi dan menghilang beberapa jam kemudian hingga satu sampai tiga hari. Nyeri ini terjadi akibat adanya pengeluaran prostaglandin yang berlebih sehingga menyebabkan vasokontriksi dan kontraksi pada uterus yang menimbulkan rasa nyeri. Prostaglandin dilepaskan akibat adanya respon dari penurunan progesteron yang terjadi saat memasuki fase menstruasi. Oleh karena itu saat progesteron mulai kembali diproduksi, maka secara perlahan prostaglandin akan berkurang dan nyeri tidak terjadi lagi. Tingginya kadar prostaglandin berhubungan dengan kontraksi uterus dan nyeri. ${ }^{17}$

Hasil penelitian ini menunjukkan bahwa terdapat hubungan bermakna antara depresi dengan dismenore. Hasil penelitian ini didukung oleh Hong et $\mathrm{al}^{7}$ dan Habibi et $\mathrm{al}^{8}$ yang menyatakan bahwa terdapat hubungan antara faktor depresi dengan dismenore. Depresi pada remaja biasanya tidak terdiagnosis sejak awal dan baru terdiagnosis setelah mereka mengalami kesulitan serius di sekolah maupun pada saat menyesuaikan diri dengan teman sebayanya. ${ }^{22} \mathrm{Hal}$ ini diperkirakan disebabkan oleh beberapa respon gangguan depresi yang tidak terlalu berbeda dengan karakteristik kondisi emosi remaja. Remaja digambarkan sebagai masa mengalami kekacauan emosi. ${ }^{23}$ Women's health melaporkan sebanyak $48 \%$ remaja yang menderita depresi dan mengalami nyeri saat menstruasi. Depresi dapat mengganggu kerja sistem endokrin, sehingga dapat menyebabkan menstruasi yang tidak teratur dan rasa sakit saat menstruasi atau dismenorea. ${ }^{24}$

\section{SIMPULAN}

Faktor-faktor yang berhubungan dengan kejadian dismenore ialah aktivitas fisik dan depresi sedangkan faktor-faktor yang tidak berhubungan ialah status gizi, usia menarche, serta lama menstruasi. Faktor yang paling dominan berhubungan dengan kejadian dismenore ialah aktivitas fisik.

\section{Konflik Kepentingan}

Penulis menyatakan tidak terdapat konflik kepentingan dalam studi ini.

\section{DAFTAR PUSTAKA}

1. Sherwood L. Fisiologi Manusia dari Sel ke Sistem (6th ed). Jakarta: EGC, 2012.

2. Ganong WF. Buku Ajar Fisiologi Kedokteran (24th ed). Jakarta: EGC, 2012.

3. Fahmi. Hubungan antara dismenore dengan usia menarche dan indeks massa tubuh. (Online). 2014. [cited 2020 Jan 11]. Available from: http://repository.usu. ac.id/

4. Larasati TA, Alatas F. Dismenore primer dan faktor risiko dismenore primer pada remaja. Majority. 2016;5(3);80.

5. Parker MA, Sneddon AE, Arbon P. The menstrual disorder of teenagers (MDOT) study: determining typical menstrual patterns and menstrual disturbance in a large populationbased study of Australian teenagers. BJOG. 2010;117(2):18592.

6. Mardhiyah U, Rosidi A, Purwanti IA. Pola dysmenorrhea primer pada remaja di MAN 1 Semarang. Semarang: The 2nd University Research Coloquium, 2015; p. 260-4. ISSN 2407-9189.

7. Hong Ju, Jones M, Mishra GD. The prevalence and risk factors of dysmenorrhea. Epidemiol Rev. 2014;36(104):104-13.

8. Habibi N, Huang MSL, Gan WY, Zulida R, Safavi SM. 2015. Prevalence of primary dysmenorrhea and factors associated with its intensity among undergraduate students: a cross-sectional study. Pain Manag Nurs. 2015;16(6):855-61.

9. WHO. 2020. WHO Timeline-COVID-19. [cited 2020 Jan 11]. Available from: https://www.who.int/news-room/detail/ 27-04-2020-who-timeline---covid-19

10. Gugus Tugas Percepatan Penanganan Covid19. Pedoman Penanganan Cepat Medis dan Kesehatan Masyarakat COVID-19 di Indonesia. Jakarta, 2020. Available from: https://infeksiemerging.kemkes. go.id

11. Guyton AC, Hall JE. Textbook of Medical Physiology (12th ed). Singapore: Elsevier, 2014.

12. Sugiyono. Metode Penelitian Kuantitatif, Kualitatif, dan R\&D. Bandung: Alfabeta, 2017.

13. Handayani E, Rahayu LS. Faktor-faktor yang berhubungan dengan nyeri menstruasi (dismenore) pada remaja putri di beberapa SMA di Kabupaten Rokan Hulu. Jurnal Maternity and Neonatal. 
2014;1(4):161-71.

14. Sadoso S. Pengetahuan Praktis Kesehatan dalam Olahraga. Jakarta: Gramedia, 2006.

15. Bahri A, Afriwardi, Yusrawati. Hubungan antara kebiasaan olahraga dengan dismenore pada mahasiswi pre-klinik Program Studi Pendidikan Dokter Fakultas Kedokteran Universitas Andalas tahun ajaran 2012-2013. Jurnal Kesehatan Andalas. 2015;4(3):815-20.

16. Suliawati G. Hubungan umur, paritas dan status gizi dengan kejadian dismenore pada wanita usia subur di Gampong Klieng Cot Aron Kecamatan Baitussalam Aceh Besar [Skripsi]. Banda Aceh: STIKES U'Budiyah; 2013.

17. Silvana PD. Hubungan antara karakteristik individu, aktivitas fisik, dan konsumsi produk susu dengan dysmenorrhea primer pada mahasiswi FIK dan FKM UI Depok tahun 2012. [Thesis]. Jakarta: Universitas Indonesia; 2012.

18. Aprillita T. Gambaran dismenorea mahasiswi Jurusan Kebidanan di Politeknik Kesehatan Kementerian Kesehatan Palangka Raya [Karya Tulis Ilmiah]. Palangka Raya: Poltekkes Kemenkes Palangka
Raya; 2013.

19. Suwarnisih, Austin K, Cahyaningtyas AY. Hubungan usia menarche dengan kejadian dismeore pada remaja putri di SMPN 17 Surakarta. Maternal. 2017; 2(1):46-54.

20. Widjanarko B. Dismenore tinjauan terapi pada dismenore primer. Majalah Kedokteran Damianus. 2006;5(1).

21. Gustina T. Hubungan antara usia menarche dan lama menstruasi dengan kejadian dismenore primer pada remaja putri di SMK Negeri 4 Surakarta [Skripsi]. Surakarta: Universitas Muhammadiyah Surakarta; 2015.

22. Lubis NL. Depresi: Tinjauan Psikologis. Jakarta: Kencana, 2009.

23. Santrock JW. Adolescence (11th ed). Boston: McGraw Hill International Edition, 2003.

24. Hailemeskel S, Demissie A, Assefa N. Primary dysmenorrhea magnitude, associated risk factors, and its effect on academic performance: evidence from female university students in Ethiopia. International Journal of Women's Health. 2016;8:489-96. 